\title{
PHYSICOCHEMICAL, PHYTOCHEMICAL AND HIGH-PERFORMANCE THIN LAYER CHROMATOGRAPHY ANALYSIS OF THE ROOT BARKS OF ONOSMA ECHIOIDES
}

\author{
AMBREEN SHOAIB ${ }^{1}$, HEFAZAT HUSSAIN SIDDIQUI ${ }^{1}$, BADRUDDEEN ${ }^{1}$, ALEZA RIZVI ${ }^{1}$, RAKESH KUMAR DIXIT ${ }^{2 *}$ \\ ${ }^{1}$ Department of Pharmacology, Faculty of Pharmacy, Integral University, Lucknow, Uttar Pradesh, India. ${ }^{2}$ Department of Pharmacology,
} King George Medical University, Lucknow, Uttar Pradesh, India. Email: Kumardixitrakesh94@gmail.com

Received: 17 May 2017, Revised and Accepted: 12 June 2017

\section{ABSTRACT}

Objective: Onosma echioides (OE) L., family Boraginaceae, is most recurrently used remedial herb, which is extensively dispersed all over India. It is used as purgative, bladder obstacle, liver chaos, kidney obstruction, sciatic pain, and gout. The study was meant to carry out the physicochemical, phytochemical, and high-performance thin layer chromatography (HPTLC) analysis on root bark of OE.

Methods: The physicochemical parameters were carried out as per the World Health Organization guideline. The preliminary chemical test was performed as per pharmacopeia and conventional methods. Camag HPTLC system equipped with TLC autosampler 4 applicator, TLC scanner 3 and win CATS 1.4.4. Software was used for HPTLC analysis of plant extract with standard, i.e., shikonin. The extracts were developed using toluene:ethyl acetate:formic acid (5:4:0.3) as a mobile phases using standard procedures and scanned under ultraviolet $254 \mathrm{~nm}$ and $366 \mathrm{~nm}$

Results: OE is composed of sterols, tannins, alkaloids, flavonoids, glycoside, saponin, and carbohydrates. The plant was found to be free from adulteration and contamination. The fluorescence characteristics of leaf powder were studied both in visible light and ultraviolet light (254 nm and $365 \mathrm{~nm}$ ) after treatment with various reagents. The TLC plate showed several spots at different Rf when viewed under $254 \mathrm{~nm}, 366 \mathrm{~nm}$. The HPTLC profile showed several peaks that indicated the presence of various phytochemicals along with its active constituent, i.e., shikonin.

Conclusion: The study provides referential information for the standardization of the plant. The HPTLC profile will help in authentication and standardization of the plant.

Keywords: Onosma echioides, High-performance thin layer chromatography, Phytochemical screening, Standardization.

(C) 2017 The Authors. Published by Innovare Academic Sciences Pvt Ltd. This is an open access article under the CC BY license (http://creativecommons. org/licenses/by/4. 0/) DOI: http://dx.doi.org/10.22159/ajpcr.2017.v10i10.20064

\section{INTRODUCTION}

Onosma echioides (OE) L., family Boraginaceae, is most recurrently used remedial herb, which is extensively dispersed all over India, Nepal, Pakistan, China, and Afghanistan [1]. It is commonly known as Maha rangi, Ratan jot and Maharanga [2-4]. Ratan jot is traditionally used in Indian food and lends its red color to some versions of the curry dish like Rogan Josh. The leaves of $\mathrm{OE}$ are widely used as a purgative, bladder obstacle, liver chaos, kidney obstruction, pain, and gout [5]. Its root pulp is utilized as an antiseptic for wounds [6], bruises and eruptions [7]. The previous study has reported the anthelmintic and alexipharmic activity of OE extract [1]. A study has revealed defending character of $\mathrm{OE}$ in croton oil urge skin malignancy and oxidative damage in Swiss mice [5]. This effect was could be owing to active constituents of shikonins and alkannins present in plant extract. Interestingly, these compounds also reported to promote wound healing in an albino rat model [8]

Recently, various extraction techniques are urbanized for the development of herbal components and its pharmacological activities [9]. Shikonin and alkannin are enantiomeric natural dyes; active components presents in the root bark of $\mathrm{OE}$, which possess immense application in pharmaceuticals, cosmetics and food colorants along with their other derivatives, such as deoxyshikonin, acetylshikonin, and hydroxyalkanin [10].

In this study, the physicochemical parameters of the plant were studied, and the n-hexane, chloroform, methanol, and aqueous extracts of the dried root bark of OE were subjected to preliminary phytochemical screening and high-performance thin layer chromatography (HPTLC) analysis.

\section{METHODS}

\section{Plant collection and authentication}

Dried root bark of OE (crude form) was procured from the authenticated licensed shop from Lucknow, India. The authenticity of plant material was confirmed from the text report of National Botanical Research Institute, Lucknow, India, and a reference specimen (voucher no. NBRI/ CIF/397/2013) was deposited. The dried plant material was coarsely powdered for the determination of ash values, extractive values, preliminary phytochemical investigation and HPTLC analysis as per standard methods.

\section{Plant extraction}

Sequential extraction of dried root bark of $\mathrm{OE}$ was performed by refluxed on water bath for $6 \mathrm{hrs}$ at $60^{\circ} \mathrm{C}$ using different solvents on the basis of increasing polarity, viz., n-hexane, chloroform, and methanol. Rotary evaporator (BUCHI Rotavapor R-205, Switzerland) was used to concentrate the filtrates obtained under vacuum at $40^{\circ} \mathrm{C}$. The extractive yields of n-hexane, chloroform, methanol, and aqueous extracts were calculated.

\section{Physicochemical parameters}

Several parameters were assessed such as extractive values in different solvents, fluorescent analysis, total ash, acid-insoluble ash, watersoluble ash, foreign matter, and moisture content using standard methods. Calibrated digital $\mathrm{pH}$ meter was used to measure the $\mathrm{pH}$ of 1 and $10 \%$ aqueous extracts $[11,12]$

\section{Preliminary phytochemical screening}

Preliminary phytochemical screening of n-hexane, chloroform, methanol, and aqueous was carried out for the detection of various compounds using standard procedures [13-15]. 
TLC and HPTLC analysis

Slurry of silica gel G was prepared in distilled water and poured over glass plates to form a thin layer. The prepared plates were air dried for setting and then kept in an oven at $100-120^{\circ} \mathrm{C}$ (30 minutes) for activation. The extracts were dissolved in respective solvents and spotted over an activated plate $(1 \mathrm{~cm}$ above from the bottom). The spotted plates were kept in a previously saturated developing chamber containing mobile phase, and allowed to run $3 / 4^{\text {th }}$ of the height of the prepared plate 20 . The plates were air dried, and number of spots were noted and Rf value was calculated [16]

The instrument employed was Camag HPTLC system (Muttenz, Switzerland) equipped with a sample applicator TLC Linomat 5 Application (Camag) with win CATS software version 1.4.4. The plate was developed using different solvent systems for each extract in a pre-saturated Camag Twin through Chamber. The mobile phase used for developing the n-hexane extract was toluene:ethyl acetate:formic acid in the ratio of 5:4:0.3 v/v, respectively. The plate was developed, removed from the chamber and allowed to dry. The developed plate was scanned using TLC Scanner 3 and analyzed with win CATS software version 1.4.4. At $\lambda \max 254 \mathrm{~nm}$ and $366 \mathrm{~nm}$ using deuterium light source, the slit dimensions were $5.00 \mathrm{~mm} \times 0.45 \mathrm{~mm}$. The chromatograms were recorded.

\section{RESULTS AND DISCUSSION}

\section{Macroscopical characteristics}

These are reddish color root having several layers which are twisted and modestly coarse (Fig. 1). Externally the roots are cylindrical, sometimes furrowed. Segments are irregularly formed approximately 6-11 cm long and 2-6 cm in diameters. It has a characteristics odor.

As the part of standardization study, the macroscopic examination of root bark was studied. Macroscopical evaluation is a technique of qualitative assessment based on the study of morphological and organoleptic characters. Macroscopical characters of root bark can serve as diagnostic characters.

\section{Physicochemical analysis}

The physicochemical characters of powdered drug of root bark of $\mathrm{OE}$ were evaluated. The extraction was done using different solvents such as n-hexane, chloroform, methanol, and water. Other parameters were also investigated, viz., ash value, acid-insoluble ash, water-soluble ash, loss on drying, fluorescent analysis, and foreign matter are presented in Table 1. Total ash is important for evaluating the purity and quality of the herb. A high ash value is indicative of contamination, substitution or adulteration. An increase in acid-insoluble ash indicates contamination with sand and soil [17]. Due to less acid insoluble value, it was found that the plant is free from adulteration and contamination of soil. The fluorescence analysis of the powdered drug of $\mathrm{OE}$ in various solvents was performed under normal and ultraviolet (254 nm and $366 \mathrm{~nm}$ ) light and powdered drug reaction with different reagents were evaluated in Tables 2 and 3, respectively. The $\mathrm{pH}$ of $1 \%$ and $10 \%$ aqueous solution of powdered drug of OE were tabulated in Table 4.

The results showed greater extractive values in successive extraction indication the effect of polarity of solvent. Their percentages were calculated with reference to air dried drug. The percent extractives in different solvents indicated quantity and nature of constituents in the extracts. The extractive values were also helpful in determining the soluble nature of a particular constituent in a particular solvent.

The fluorescence analysis of the root bark of $\mathrm{OE}$ was performed using various solvents and was performed under normal and UV light.

\section{Preliminary phytochemical screening}

The preliminary phytochemical investigation of OE showed in Table 5, which showed the presence of sterols, flavonoids, glycosides, phenolic compounds, carbohydrates, and alkaloids.

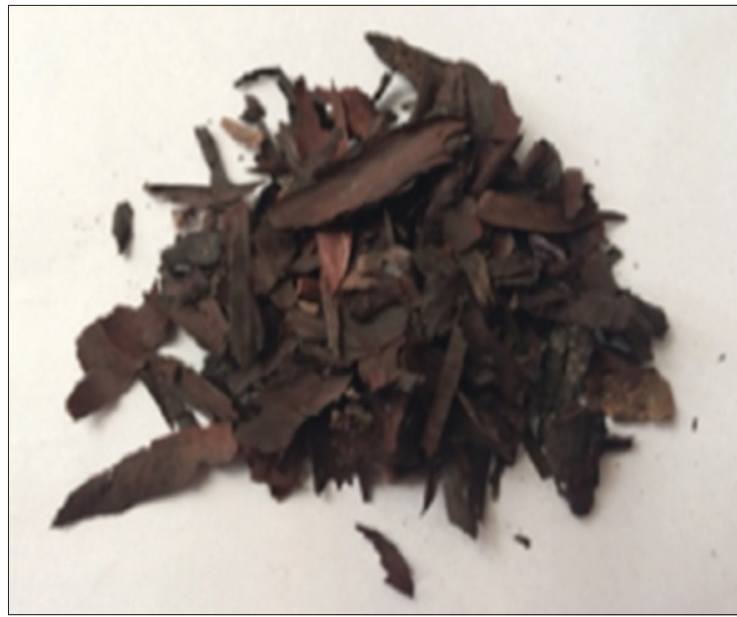

Fig. 1: Root barks of Onosma echioides

Table 1: Physicochemical parameters of Onosma echioides

\begin{tabular}{ll}
\hline Quantitative parameter & Values obtained (\%) w/w \\
\hline n-hexane extractive & 8.3 \\
Chloroform extractive & 3.6 \\
Alcohol soluble extractive & 4.6 \\
Water-soluble extractive & 11.4 \\
Total ash & 10.66 \\
Acid-insoluble ash & 4.83 \\
Water-soluble ash & 12.66 \\
Loss on drying & 4.7 \\
Foreign matter & 0.76 \\
\hline
\end{tabular}

Table 2: Florescent analysis of Onosma echioides in different solvent system

\begin{tabular}{|c|c|c|c|}
\hline $\begin{array}{l}\text { Solvent } \\
\text { used }\end{array}$ & Daylight & $\begin{array}{l}\text { UV light } \\
\text { (254 nm) }\end{array}$ & $\begin{array}{l}\text { UV light } \\
\text { (366 nm) }\end{array}$ \\
\hline Benzene & $\begin{array}{l}\text { Grayish } \\
\text { brown }\end{array}$ & Greenish brown & Gray \\
\hline Dist. Water & $\begin{array}{l}\text { Reddish } \\
\text { brown }\end{array}$ & Light green & Dark green \\
\hline $\begin{array}{l}\mathrm{NaOH} \text { in } \\
\text { water }\end{array}$ & $\begin{array}{l}\text { Dark } \\
\text { brown }\end{array}$ & Light green & Golden brown \\
\hline $\mathrm{NaOH}$ in & Blackish & Dark green & Black \\
\hline $\mathrm{CH}_{3} \mathrm{OH}$ & brown & & \\
\hline Chloroform & $\begin{array}{l}\text { Golden } \\
\text { brown }\end{array}$ & Yellowish green & Dark brown \\
\hline Dil. $\mathrm{HNO}_{3}$ & Brown & Light brown & Golden brown \\
\hline Acetone & $\begin{array}{l}\text { Light } \\
\text { brown }\end{array}$ & Light brown & Yellowish brown \\
\hline Ethyl acetate & $\begin{array}{l}\text { Light } \\
\text { brown }\end{array}$ & Yellow & Yellowish green \\
\hline
\end{tabular}

Table 3: Powdered drug reaction with different reagents of $\mathrm{OE}$

\begin{tabular}{ll}
\hline Treatment & Observation \\
\hline Powder as such & Reddish brown \\
Concentrated $\mathrm{HCl}$ & Brown \\
Concentrated $\mathrm{HNO}_{3}$ & Brownish Yellow \\
Concentrated $\mathrm{H}_{2} \mathrm{SO}_{4}$ & Yellowish brown \\
Glacial acetic acid & Brownish red \\
Benzene & Grayish brown \\
NaOH in methanol & Gray \\
\hline
\end{tabular}

OE: Onosma echioides 
TLC

TLC of n-hexane extract was carried out using toluene:ethyl acetate:formic acid in the ratio of 5:4:0.3, respectively, and the $\mathrm{Rf}$ values were recorded (Fig. 2) and depicted in Table 6. The visualizing reagent employed was anisaldehyde-sulfuric acid reagent to effect visualization of the resolved spots.

TLC is also valuable for the preliminary separation and determination of plant constituents. The chromatographic value may serve as a characteristics print for quantitative evaluation of root bark of $\mathrm{OE}$.

\section{HPTLC of OE n- hexane extract}

HPTLC fingerprinting is a valuable tool for the evaluation of herbal medicine. This study was conducted for the quantitative determination

Table 4: Determination of $\mathrm{pH}$ of $\mathrm{OE}$

\begin{tabular}{lc}
\hline Aqueous solution (\%) & $\mathbf{p H}$ \\
\hline 1 & 5.0 \\
10 & 6.2 \\
\hline OE: Onosma echioides &
\end{tabular}

Table 5: Preliminary phytochemical screening of OE n-hexane extract

\begin{tabular}{ll}
\hline Tests & n-hexane extract of $\mathbf{~ O E}$ \\
\hline Test for sterols & + \\
Tannins test & - \\
Flavonoids & + \\
Test protein and amino acid & - \\
Glycosides test & + \\
Phenolic test & + \\
Carbohydrate test & + \\
Saponin test & + \\
Alkaloids test & + \\
\hline
\end{tabular}

OE: Onosma echioides

Table 6: TLC of $n$-hexane extract of $\mathrm{OE}$

\begin{tabular}{llll}
\hline $\begin{array}{l}\text { Test } \\
\text { extracts }\end{array}$ & Solvent system & $\begin{array}{l}\text { Number } \\
\text { of spots }\end{array}$ & Rf value \\
\hline n-hexane & $\begin{array}{l}\text { Toluene:ethyl acetate: } \\
\text { formic acid: } 5: 4: 0.3\end{array}$ & 5 & $0.97,0.9,0.82$, \\
& & $0.76,0.65$ \\
\hline
\end{tabular}

TLC: Thin layer chromatography, OE: Onosma echioides of phytochemicals present in the plant extract [18]. HPTLC of n-hexane extract of OE was carried out using the same solvent as that in TLC. Toluene:ethyl acetate:formic acid in the ratio of 5:4:0.3, respectively, and the Rf values were recorded. The densitogram of $n$-hexane extract $\mathrm{OE}$ and its active constituent, i.e., shikonin was scanned and analyzed with win CATS software version 1.4.4. At $\lambda$ max $254 \mathrm{~nm}$ and $366 \mathrm{~nm}$ using deuterium light source, the slit dimensions were $5.00 \mathrm{~mm} \times$ $0.45 \mathrm{~mm}$. The chromatograms were showed in Fig. 3 and peak table for HPTLC profile of OE was showed in Table 7. Whereas, peak table for HPTLC profile of shikonin was recorded in Fig. 4 and illustrated in Table 8, which showing the presence of shikonin in OE n-hexane extract.

\section{CONCLUSION}

It can be concluded that the present study on root bark of OE can serve as an important source of information to ascertain the identity and to determine the quality and purity of plant material available in the market. These parameters are necessary for the identification of drugs. The presence of various chemical constituents in $\mathrm{OE}$ may be a potential cause of treatment of various disorders. The quality of the plant can be estimated by determining the physical parameters. These investigations are of great importance for carrying out the revalidation and estimation of its other pharmacological activities.

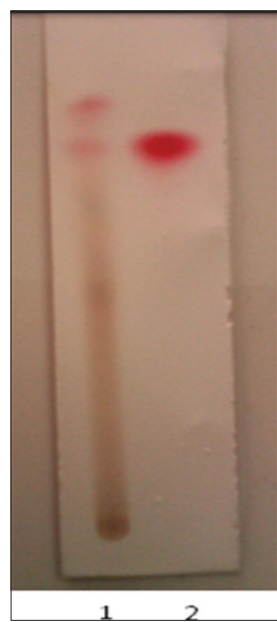

Fig. 2: Fingerprinting profile: (1) n-hexane extract of Onosma echioides (2) Shikonin

Table 7: Peak table for HPTLC profile of OE n- hexane extract

\begin{tabular}{|c|c|c|c|c|c|c|c|c|c|c|}
\hline \multicolumn{11}{|c|}{ Track 1, ID: OE } \\
\hline Peak & $\begin{array}{l}\text { Start } \\
\text { position (Rf) }\end{array}$ & $\begin{array}{l}\text { Start } \\
\text { height (AU) }\end{array}$ & $\begin{array}{l}\text { Max } \\
\text { position (Rf) }\end{array}$ & $\begin{array}{l}\text { Max } \\
\text { height (AU) }\end{array}$ & $\operatorname{Max}(\%)$ & $\begin{array}{l}\text { End } \\
\text { position (Rf) }\end{array}$ & $\begin{array}{l}\text { End } \\
\text { height (AU) }\end{array}$ & Area $(A U)$ & Area (\%) & $\begin{array}{l}\text { Assigned } \\
\text { substance }\end{array}$ \\
\hline 1 & 0.00 & 0.3 & 0.02 & 75.9 & 15.72 & 0.03 & 17.1 & 1022.3 & 4.26 & Unknown* \\
\hline 2 & 0.04 & 17.2 & 0.04 & 20.5 & 4.25 & 0.06 & 9.1 & 333.7 & 1.39 & Unknown* \\
\hline 3 & 0.39 & 9.3 & 0.42 & 17.4 & 3.61 & 0.44 & 15.1 & 552.1 & 2.30 & Unknown* \\
\hline 4 & 0.46 & 18.5 & 0.50 & 29.5 & 6.12 & 0.50 & 27.3 & 948.6 & 3.96 & Unknown* \\
\hline 5 & 0.61 & 37.0 & 0.69 & 165.4 & 34.27 & 0.74 & 74.9 & 11486.0 & 47.90 & Unknown* \\
\hline 6 & 0.74 & 74.9 & 0.79 & 145.4 & 30.12 & 0.85 & 8.0 & 9093.7 & 37.93 & Shikonin \\
\hline 7 & 0.86 & 3.3 & 0.88 & 28.5 & 5.90 & 0.90 & 0.2 & 540.9 & 2.26 & Unknown* \\
\hline
\end{tabular}

OE: Onosma echioides. ${ }^{*}$ Shows the unknown components present in plant extract

Table 8: Peak table for HPTLC profile of shikonin

\begin{tabular}{|c|c|c|c|c|c|c|c|c|c|c|}
\hline \multicolumn{11}{|c|}{ Track 2, ID: Shikonin } \\
\hline Peak & $\begin{array}{l}\text { Start } \\
\text { position }\end{array}$ & $\begin{array}{l}\text { Start } \\
\text { height }\end{array}$ & $\begin{array}{l}\text { Max } \\
\text { position }\end{array}$ & $\begin{array}{l}\text { Max } \\
\text { height }\end{array}$ & Max \% & $\begin{array}{l}\text { End } \\
\text { position }\end{array}$ & $\begin{array}{l}\text { End } \\
\text { height }\end{array}$ & Area & Area \% & $\begin{array}{l}\text { Assigned } \\
\text { substance }\end{array}$ \\
\hline 1 & $0.76 \mathrm{Rf}$ & $1.3 \mathrm{AU}$ & $0.81 \mathrm{Rf}$ & 108.7 AU & 100.00 & $0.84 \mathrm{Rf}$ & $1.5 \mathrm{AU}$ & $4937.0 \mathrm{AU}$ & 100.00 & Shikonin \\
\hline
\end{tabular}



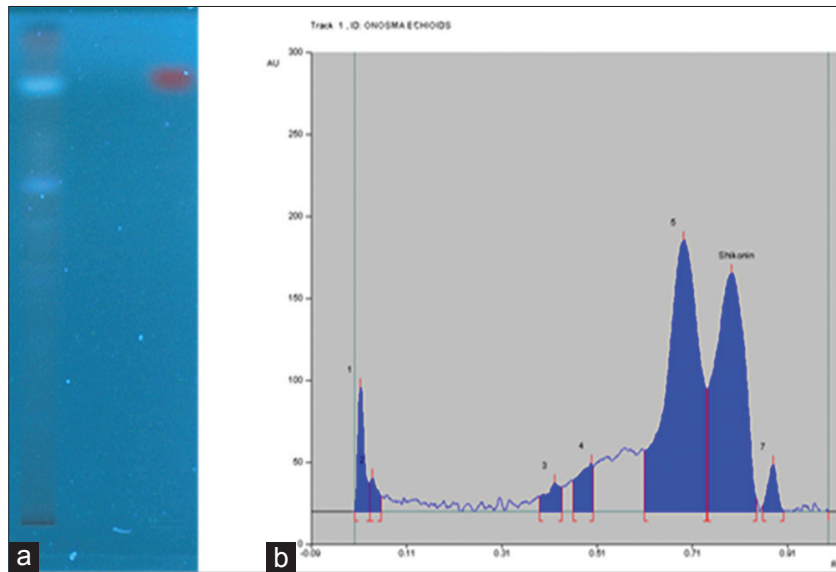

Fig. 3: (a) High-performance thin layer chromatography fingerprinting of n-hexane of Onosma echioides (OE) scanned at wavelength at $366 \mathrm{~nm}$ and (b) densitogram of $\mathrm{n}$-hexane of $\mathrm{OE}$ scanned at wavelength at $366 \mathrm{~nm}$

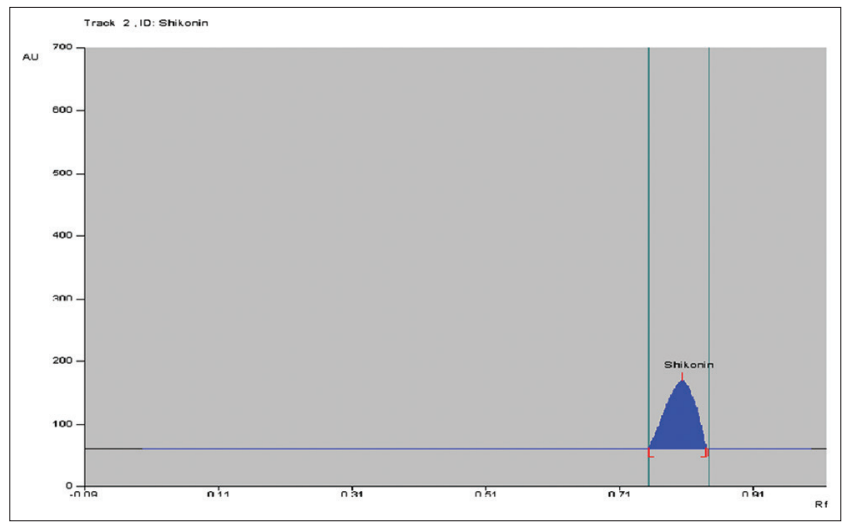

Fig. 4: High-performance thin layer chromatography fingerprinting of shikonin the active constituent of Onosma echioides as a reference standard at $366 \mathrm{~nm}$

\section{ACKNOWLEDGMENT}

The authors are thankful to Integral University, Lucknow, for the encouragement and the facilities provided (IU/R\&D/2017-MCN00094).

\section{REFERENCES}

1. Kumar N, Kumar R, Kishore K. Onosma L.: A review of phytochemistry and ethnopharmacology. Pharmacogn Rev 2013;7(14):140-51.

2. Sharma GK. Medical plant folklore and the Ayurvedic system of medicine in the Indo-Tibetan outer Himalaya. J Tenness Acad Sci 2000;75:38-1.

3. Baral SR, Kurmi PP. Compendium of Medicinal Plants in Nepal. Chabahil, Kathmandu, Nepal: Rachana Sharma Publishers; 2006. p. 534 .

4. Bharttarai S, Chaudhary RP, Taylor RS. Ethnomedical plants used by the people of Manang district, central Nepal. J Ethnobiol Ethnomed 2006;2:41-8.

5. Sharma S, Khan N, Sultana S. Effect of Onosma echioides on DMBA/ croton oil mediated carcinogenic response, hyperproliferation and oxidative damage in murine skin. Life Sci 2004;75:2391-410.

6. Roeder E, Wiedenfeld H. Pyrrolizidine alkaloids in medicinal plants of Mongolia, Nepal and Tibbet. Pharmazie 2009; 64(11): 699-16. Doi: $10.1691 / \mathrm{ph} .2009 .9653$.

7. Chopra RN, Nayar SL, Chopra IC, Asolkar LV, Kakkar KK, Chakre OJ, Verma BS. Glossary of Indian Medicinal Plants. New Delhi, India: National Institute of Science Communication; 1996. p. 1956-92.

8. Nikita G, Vivek P, Chhaya G. Wound-healing activity of an oligomer of alkannin/shikonin, isolated from root bark of Onosma echioides. Nat Prod Res 2015;29(16):1584-8.

9. Omkar A, Jeej T, Chhaya G. Evaluation of anti-inflammatory activity of Nyctanthes arbortristis and Onosma echioides. Pharmacogn Mag 2006;2(8):258-60.

10. Bairagi N, Gulrajani ML. Studies on dyeing with shikonin extracted from ratanjot by Supercritical carbon dioxide. Indian J Fibre Text Res 2005;30:196-9.

11. Ansari SH. Standardization of crude drugs. Essential of Pharmacognosy. New Delhi: Birla Publication Private Limited; 2008. p. 575-96.

12. Kamath CR, Shah B. Phytochemical screening and standardization of polyherbal formulation: Maharishi Amrit Kalash. Int J Pharm Pharm Sci 2014;6(7):96-8.

13. Harborne JB. Phytochemical Methods, Guide to Modern Techniques of Plant Analysis. $3^{\text {rd }}$ ed. New Delhi: Springer (India) Pvt. Ltd.; 1998. p. 5-2.

14. Khandelwal KR. Technique and experiments. Practical Pharmacognosy, Appendix 1. $19^{\text {th }}$ ed New Delhi: Nirali Prakashan; 2008. p. 183.

15. Saini S, Dhiman A, Nanda S. Pharmacognostical and phytochemical studies of Piper betle Linn. Leaf. Int $\mathrm{J}$ Pharm Pharm Sci 2016;8(5):222-6.

16. Controller of Publications. Indian Pharmacopoeia, Apendix 3. Vol 2. New Delhi: Controller of Publications; 1996.

17. Sharma PK, Mohammad A, Yadav DK. Physico-chemical and phytochemcial evaluation of different tea brands. J Appl Pharm Sci 2011;1(3):121-4.

18. Hariprasad PS, Ramakrishnan N. HPTLC fingerprint profile of Rumex vesicarius L. Asian J Pharm Clin Res 2011;4(2):134-6. 